DOI: $\underline{10.35619 / \text { iiu.v1i13.390 }}$

Генсіцька-Антонюк Наталія

кандидат педагогічних наук, доцент кафедри математики з методикою викладання Рівненського державного гуманітарного університету, м. Рівне, Україна ORCID: 0000-0002-5845-8343 e-mail:nataliia.hensitska-antoniuk@rshu.edu.ua

\title{
ПОГЛЯДИ УКРАЇНСЬКИХ ПЕДАГОГІВ НА РОЗРОБКУ ДИДАКТИЧНИХ ЗАСАД ТВОРЕННЯ ПІДРУЧНИКІВ 3 МАТЕМАТИКИ
}

Анотація. У статті проаналізовано погляди українських педагогів на розробку дидактичних засад створення підручників 3 математики. Зазначено, що зміст шкільних підручників $є$ втіленням не лише навчальних планів і програм, а й системи цінностей певної культури, що відіграє важливу роль у соціалізації підростаючого покоління. Наголошено, що підручник - це основний засіб навчання, що грунтується на загальнодидактичних та методичних принципах навчання. Виділено дидактичні принципи: активізації пізнавальної діяльності учнів, всебічного розвитку особистості, цілісного впливу освітнього процесу, природовідповідності організації навчання, науковості, доступності, системності та послідовності у навчанні, наступності та перспективності, взаємозв'язку навчання та розвитку, мотиваційного забезпечення освітнього процесу, співробітництва, індивідуалізації та диференціації навчання, наочності, міцності та дієвості результатів навчання, активності, виховуючого навчання, свідомості, інтенсивності, оптимізації, міжпредметної кооперації, міжкультурної взаємодії тощо. Обгрунтовано, що серед підходів до визначення дидактичних засад підручника особливе місце займає функціональний підхід, за яким основними функціями шкільного підручника $€$ : інформативна, трансформаційна, систематизуючи, дослідницька, практична та самоосвітня функція.

Акцентовано увагу, що шкільні підручники 3 математики допомагають створити цілісну систему навчання учнів математики 3 єдиним однозначним тлумаченням понять, уніфікованою термінологією та забезпечують не лише кінцевий результат навчання, а й виконання виховних, розвивальних функцій - формування високоосвіченої, всебічно розвиненої творчої особистості, національно свідомого громадянина України.

Ключові слова: підручники 3 математики, погляди українських педагогів, дидактичні засади творення підручників. 


\section{Інноватика у вихованні. Випуск 13.Том 1. 2021.}

Постановка проблеми. Нині заклад загальної середньої освіти $\epsilon$ важливим соціальним інститутом, в межах якого особистість дитини розвивається, набуває соціального досвіду, вчиться самостійності та творчості. Тому повноцінний розвиток учнів $є$ одним 3 пріоритетних завдань сучасної освітньої політики, про що зазначено в державних нормативних документах: Законах України «Про освіту» (2017), «Про повну загальну середню освіту» (2020), Концепції «Нова українська школа» (2016) та ін. Вирішення цього завдання великою мірою залежить від змісту освіти в закладі середньої освіти, у т.ч. й змісту шкільних підручників.

Аналіз останніх досліджень із проблеми. Аналіз психологопедагогічних джерел засвідчив, що ця проблема була предметом дослідження науковців. Зокрема, I. Підласий досліджував дидактичну модель навчальних предметів та ії реалізацію у структурі й змісті підручника (Підласий, 2004). Сучасна українська вчена Я. Кодлюк досліджує процес творення підручника у галузі освіти України в умовах державної незалежності (Кодлюк, 2005). Відомий український методист I. Смагін обгрунтував новий методологічний підхід до дослідження проблем шкільного підручникотворення (Смагін, 2009). Нами здійснено гендерний аналіз шкільних підручників з математики (Генсіцька-Антонюк, 2015).

Мета статті - проаналізувати погляди українських педагогів на розробку дидактичних засад творення підручників з математики.

Виклад основного матеріалу дослідження. Українська бібліотечна енциклопедія визначає підручник як навчальне видання, що містить основи наукових знань та видів діяльності з певної навчальної дисциплін, викладені відповідно до державних стандартів освіти та вимог офіційно затвердженої навчальної програми 3 урахуванням особливостей цієї дисципліни (Підручник, 2018). Отже, підручник $є$ ключовим компонентом освітнього процесу та потребує визначення основних підходів до розробки дидактичних засад його створення.

Підручник - це не лише педагогічне явище, а й соціальне, позаяк багатство та різновекторність змісту підручника робить його цінним документом. Г. Розлуцька зазначає, що підручник як «носій змісту освіти $\epsilon$ відображенням певної епохи, рівня знань, світогляду і домінуючих стереотипів, іншими словами - це педагогічний документ, вписаний у тривалу педагогічну традицію, невіддільний від часу виникнення, достовірне віддзеркалення методів викладання в тодішніх умовах» (Розлуцька, 2006, с.10). Варто відзначити, що шкільний підручник - це своєрідне втілення не лише навчальних планів і програм, а й системи цінностей певної культури, що відіграє важливу роль у соціалізації підростаючого покоління.

Також, підручник $є$ основним джерелом знань та найважливішим засобом навчання. Навчальний матеріал, що вміщений у підручнику, повинен бути доступним, цікавим, відповідати віковим потребам 


\section{Інноватика у вихованні. Випуск 13.Том 1. 2021.}

здобувачів освіти. Систематичний виклад навчального матеріалу в підручнику повинен здійснюватися в єдності 3 методами пізнання й відрізнятися популярністю, захопливістю, проблемністю. Тільки так підручник як дидактичний засіб навчання i як джерело самостійного здобування учнем знань може викликати зацікавленість учня до знань і самого процесу пізнання, стимулювати в нього потребу в самоосвіті (Генсіцька-Антонюк, 2014, с.38).

Дослідник I. Смагін зазначає, що у межах предметної освітньої системи підручник знаходиться у взаємодії з іiі іншими елементами. Результати цієї взаємодії можна прослідкувати у перевиданнях навчальної книги у межах однієї освітньої системи. Зміни у змісті і формі викладення навчального матеріалу в новому виданні навчальної книги відображають певні зміни в методиці навчання, дидактиці в цілому, зміни в нормативних вимогах до предмета тощо. Відповідність підручника вимогам оптимальної взаємодії 3 іншими елементами освітньої системи $\epsilon$ конкретно-історичним критерієм оцінки навчальної книги (Смагін, 2009).

Підручник виступає основним засобом навчання та повинен спиратися як на загальнодидактичні, так і на суто методичні принципи навчання. До сучасних дидактичних принципів відносимо: принцип активізації пізнавальної діяльності учнів, принцип всебічного розвитку особистості, принцип цілісного впливу освітнього процесу, принцип природовідповідності організації навчання, принцип науковості, принцип доступності, принцип системності та послідовності у навчанні, принцип наступності та перспективності, принцип взаємозв'язку навчання та розвитку, принцип мотиваційного забезпечення освітнього процесу, принцип співробітництва, принцип індивідуалізації та диференціації навчання, принцип наочності, принцип міцності та дієвості результатів навчання, принцип активності, принцип виховуючого навчання, принцип свідомості, принцип інтенсивності, принцип оптимізації, принцип міжпредметної кооперації, принцип міжкультурної взаємодії тощо.

Українська дослідниця Я. Кодлюк переконана, що підручник повинен відображати змістову та процесуальну сторони освітнього процесу, тобто зміст і завдання навчання, а також методи, прийоми та організаційні форми навчання. Вона вважає, що шкільний підручник - «це вид навчальної літератури, який репрезентує знання і види діяльності 3 конкретного навчального предмета відповідно до державних стандартів освіти та вимог навчальної програми 3 урахуванням особливостей цього предмета (його домінуючої функції), типу школи, вікових особливостей учнів і будується на засадах домінуючої концепції навчання» (Кодлюк, 2005, с.11).

В «Енциклопедії освіти» (2008, с. 1005) виокремлено функції шкільного підручника, як-то: інформативна; трансформаційна; систематизуюча; дослідницька; практична; самоосвітня функція.

Функціональний підхід дає змогу встановити функціональне навантаження кожного структурного компоненту, зв’язок між ними, іншими словами, розробити структурно-функціональну модель 


\section{Інноватика у вихованні. Випуск 13.Том 1. 2021.}

підручника. Цей підхід є найбільш конструктивним на сучасному етапі розвитку підручника.

Під час укладання підручників на перший план мають висуватися характеристики навчального тексту, від яких залежить його розуміння $\mathrm{i}$ засвоєння. До таких характеристик нами віднесено інформативність та абстрактність навчального тексту, які допомагають передбачити труднощі у його розумінні та судити про доступність підручника та його придатність до експериментальної перевірки в школі.

Здійснюючи ретроспективний аналіз практики підручникотворення 3 математики з кінця XIX століття, варто відзначити, що у цьому процесі простежується певна позитивна динаміка: укладачі прагнули, щоб зміст підручників відповідав змістові навчального матеріалу, основним засадам реформування математичної освіти загалом і початкової зокрема, а також віковим особливостям учнів.

У 90-ті роки $\mathrm{XX}$ ст. простежувався сповільнений темп розвитку підручникотворення 3 математики, що пояснювалося наступними причинами: по-перше, на повну спроможність не запрацювала ще вітчизняна науково-методична думка (побачило світ лише два підручники M. Богдановича); по-друге, активно перевидавали підручники 3 математики російських авторів (наприклад, підручник з математики для 2 кл. М. Моро, М. Бантової упродовж цього десятиліття отримав 10 перевидань); по-трете, за цього періоду йшли активні творчі наукові пошуки щодо вдосконалення якості підручника.

Аналіз українських підручників 3 математики засвідчив, що найбільш затребуваним автором підручників для всіх класів початкової школи був М. Богданович: його «Математична веселка» (1991), «Математичні віночки» (1983), «Математичні джерельця» (1988) видані кількома мовами.

Авторським колективом під керівництвом М. Богдановича було розроблено нові програми та підручник з математики (М. Богданович та Л. Кочина), виготовлено роздавальні та ілюстративні матеріали (Л. Кочина). Особливістю цих підручників було врахування рівнів підготовленості учнів, для чого уперше було запроваджено три рівні складності завдань, розроблено систему логічних вправ для розвитку логічного мислення. Методист започаткував напрям розвитку пізнавальних здібностей учнів на уроках математики через систему розвивальних завдань: 3 логічним навантаженням, практичних завдань на розвиток кмітливості і переносу знань у нові ситуації та ін.

Безперечним здобутком ученого стала реалізація власних ідей у підручниках та навчальних посібниках для учнів молодшого шкільного віку.

Чималий масив у вказаному переліку зайняли пробні підручники М. Богдановича: «Математика» 1 кл. (4-річна) (1995-1997), «Математика» 1 кл. (3-річна) (1997), «Математика» 2(1) кл. (1993-1995), «Математика» 3(2) кл. (1993, 1995, 1997), «Математик»а 4(3) кл. $(1995,1997)$ та Л. Кочиної - «Математика» 1 кл. (3-річна) (1996). 


\section{Інноватика у вихованні. Випуск 13.Том 1. 2021.}

Українська дослідниця Л. Височан, досліджуючи дидактичні основи побудови підручників 3 природничо-математичних дисциплін для початкових шкіл України виокремила три основні змістові лінії матеріалу, що представлений у підручниках: арифметичний матеріал; вправи, у яких наявний геометричний матеріал та алгебраїчна пропедевтика. Варто зауважити, що найбільше в них представлено арифметичний матеріал. Алгебраїчна пропедевтика, що передбачає ознайомлення 3 рівняннями $\mathrm{i}$ нерівностями, а також основи геометричних знань подані у підручниках у кількісному відношенні майже рівномірно. У сучасних підручниках 3 математики для початкових класів вагоме місце серед текстових матеріалів (43\%) займає виробнича тематика і надто мало (усього 1,4 \%) завдань українознавчого змісту. Ілюстративний матеріал авторами підручників 3 математики підпорядкований провідній у певний період ідеї виховання дітей (Височан, 2008, с.12).

В перші роки незалежності України учні 5-9-х класів користувалися радянськими підручниками, зокрема: «Математика» для 5, 6 класів, Е. Нурк, А. Тельгма «Математика» для 5, 6 класів, Ю. Макаричев та інші «Алгебра» для 7, 8 і 9 класів, О. Погорєлов «Геометрія» для 7-9 класів.

Проте згодом 3'явились перші пробні підручники українських авторів: Г. Возняк, Г. Литвиненко, І. Маланюк «Математика» для 5 класу (1994), Г. Литвиненко, Г. Возняк «Математика» для 6 класу (1995), Г. Бевз «Математика» для 7 класу (1994), Г. Бевз «Математика» для 8 класу (1994), Г. Бевз «Математика» для 9 класу (1996), М. Кельбас «Геометрія» для 7-9 класів (1994). Варто зауважити, що деякі 3 пробних підручників друкувалися як українською, так і російською мовами. Деякі були змінено структурно. Зокрема, підручник О. Погорєлова з 1994 стали друкувати в двох книгах: окремо планіметрію і стереометрію. Окремою книгою з 1996 р. друкувалася «Алгебра 7-9» Г. Бевза.

Висновки і перспективи подальших розвідок. Отже, шкільний підручник - не лише джерело інформації, а й чинник особистісного розвитку особистості (психологічного, інтелектуального, морального, естетичного). Зміст шкільного підручника, власне, $є$ посередником між системою наукового знання й індивідуально-психологічними особливостями учнів, забезпечує їх інтелектуальний i особистісний розвиток.

Шкільні підручники 3 математики утворюють цілісну систему навчання учнів математики в 1-9-х класах 3 єдиним однозначним трактуванням понять, уніфікованою термінологією та забезпечують не лише кінцевий результат навчання, а й виконання виховних, розвивальних функцій - формування високоосвіченої, всебічно розвиненої творчої особистості, національно свідомого громадянина України. 


\section{Інноватика у вихованні. Випуск 13.Том 1. 2021.}

\section{СПИСОК ВИКОРИСТАНИХ ДЖЕРЕЛ}

Міністерство освіти і науки України. (2017). Закон Украӥни «Про освіту». URL: https://zakon.rada.gov.ua/laws/show/2145-19\#Text. [Дата звернення 25.04.21].

Міністерство освіти і науки України. (2020). Закон Украӥни «Про повну загальну середню освіту». URL: https://zakon.rada.gov.ua/laws/show/463-20\#Text. [Дата звернення 25.04.2021].

Нова украӥнська школа: концептуальні засади реформування середньої освіти. (2016). К. 40 с.

Підласий, I. (2004). Практична педагогіка або три технології: інтерактивний підручник для педагогів ринкової системи освіти. К.: Слово. 616 с.

Кодлюк, Я. (2005). Теорія і практика підручникотворення у галузі початкової освіти України (1960-2000 рр.). Доктор педагогічних наук. Тернопільський національний педагогічний ун-т ім. Володимира Гнатюка.

Смагін, I. (2009). Методологічні засади аналізу теорії і практики шкільного підручникотворення 3 суспільствознавчих навчальних предметів. Вісник Житомирського державного університету. Випуск 45. Педагогічні науки. СС. 10-14.

Генсіцька-Антонюк, Н. (2015). Особливості гендерного аналізу шкільних підручників з математики. Інноватика у вихованні: зб. наук. пр. Вип. 2. Рівне: РДГУ. СС. 149-157.

Підручник, (2018). Украӥнська бібліотечна енциклопедія. URL: https://ube.nlu.org.ua/article/\%D0\%9F\%D1\%96\%D0\%B4\%D1\%80\%D1\%83 \%D1\%87\%D0\%BD\%D0\%B8\%D0\%BA._[Дата звернення 25.04.2021].

Розлуцька, Г. (2006). Зміст икільних підручників як фактор полікультурного виховання молодших школярів у Закарпатті (1919-1939 pp.). Кандидат педагогічних наук. Житомирський державний університет ім. І. Франка.

Генсіцька-Антонюк, Н. (2014). Основні аспекти теорії підручника та підходи до розробки дидактичних засад його створення. Психологопедагогічні основи гуманізаиіі навчально-виховного процесу в школі та ВНЗ. Вип. 2. СС. 32-38.

Енциклопедія освіти. Київ: Юрінком Інтер, 2008. 1040 с.

Височан, Л. (2008). Дидактичні основи побудови підручників $з$ природничо-математичних дисииплін для початкових шкіл України (1958 - 1991pp.). Кандидат педагогічних наук. Прикарпатський національний університет імені Василя Стефаника.

\section{REFERENCES}

Ministerstvo osvity i nauky Ukrainy, (2017). Zakon Ukrainy "Pro osvit" [Law of Ukraine "On Education"] URL: https://zakon.rada.gov.ua/laws/show/2145-19\#Text. [Data zvernennia 25.04.21]. [in Ukrainian]. 


\section{Інноватика у вихованні. Випуск 13.Том 1. 2021.}

Ministerstvo osvity i nauky Ukrainy. (2020). Zakon Ukrainy "Pro povnu zahalnu seredniu osvitu" [Law of Ukraine "On Complete General Secondary Education"] URL: https://zakon.rada.gov.ua/laws/show/463-20\#Text. [Data zvernennia 25.04.21]. [in Ukrainian].

Nova ukrainska shkola: kontseptualni zasady reformuvannia serednoi osvity [New Ukrainian school: conceptual bases of secondary education reform]. (2016). K. 40 s. [in Ukrainian].

Pidlasyi, I. (2004). Praktychna pedahohika abo try tekhnolohii: interaktyvnyi pidruchnyk dlia pedahohiv rynkovoi systemy osvity [Practical pedagogy or three technologies: an interactive textbook for teachers of the market education system]. K.: Slovo. 616 s. [in Ukrainian].

Kodliuk, Ya. (2005). Teoriia i praktyka pidruchnykotvorennia u haluzi pochatkovoi osvity Ukrainy (1960-2000 rr.) [Theory and practice of textbook creation in the field of primary education in Ukraine (1960-2000)]. Doktor pedahohichnykh nauk.: Ternopilskyi natsionalnyi pedahohichnyi un-t im. Volodymyra Hnatiuka. [in Ukrainian].

Smahin, I. (2009). Metodolohichni zasady analizu teorii i praktyky shkilnoho pidruchnykotvorennia z suspilstvoznavchykh navchalnykh predmetiv [Methodological bases of the analysis of the theory and practice of school textbook creation on social science subjects]. Visnyk Zhytomyrskoho derzhavnoho universytetu. Vypusk 45. Pedahohichni nauky. SS. 10-14. [in Ukrainian].

Hensitska-Antoniuk, N. (2015). Osoblyvosti hendernoho analizu shkilnykh pidruchnykiv z matematyky [Features of gender analysis of school textbooks in mathematics]. Innovatyka u vykhovanni: zb. nauk. pr. Vyp. 2. Rivne: RDHU. SS. 149-157. [in Ukrainian].

Pidruchnyk, (2018). Ukrainska bibliotechna entsyklopediia [Ukrainian library encyclopedia]

URL: https://ube.nlu.org.ua/article/\%D0\%9F\%D1\%96\%D0\%B4\%D1\%80\%D1\%83 $\% \mathrm{D} 1 \% 87 \% \mathrm{D} 0 \% \mathrm{BD} \% \mathrm{D} 0 \% \mathrm{~B} 8 \% \mathrm{D} 0 \% \mathrm{BA}$ [Data zvernennia 25.04.21]. [in Ukrainian].

Rozlutska, H. (2006). Zmist shkilnykh pidruchnykiv yak faktor polikulturnoho vykhovannia molodshykh shkoliariv u Zakarpatti (1919 - 1939 $r r$.) [The content of school textbooks as a factor of multicultural education of junior schoolchildren in Transcarpathia (1919 - 1939)]. Kondydat pedahohichnykh nauk. Zhytomyrskyi derzhavnyi universytett im. I. Franka. [in Ukrainian].

Hensitska-Antoniuk, N. (2014). Osnovni aspekty teorii pidruchnyka ta pidkhody do rozrobky dydaktychnykh zasad yoho stvorennia [The main aspects of the textbook theory and approaches to the development of didactic principles of its creation]. Psykholoho-pedahohichni osnovy humanizatsii navchalnovykhovnoho protsesu $v$ shkoli ta VNZ. Vyp. 2. SS. 32-38. [in Ukrainian]. 
Entsyklopediia osvity [Encyclopedia of Education]. K.: Yurinkom Inter, 2008. 1040 s. [in Ukrainian].

Vysochan, L. (2008). Dydaktychni osnovy pobudovy pidruchnykiv $z$ pryrodnycho-matematychnykh dystsyplin dlia pochatkovykh shkil Ukrainy (1958 - 1991rr.) [Didactic bases of construction of textbooks on natural and mathematical disciplines for primary schools of Ukraine (1958-1991)]. Kandydat pedahohichnykh nauk. Prykarpatskyi natsionalnyi universytet imeni Vasylia Stefanyka. [in Ukrainian].

\title{
VIEWS OF UKRAINIAN TEACHERS ON THE DEVELOPMENT OF DIDACTIC BASIS FOR CREATING MATHEMATICS TEXTBOOKS
}

\author{
Nataliia Hensitska-Antoniuk \\ Candidate of Pedagogical Sciences, \\ Associate Professor at the Department of Mathematics with Teaching \\ Methods \\ Rivne State University for the Humanities, \\ Rivne, Ukraine \\ ORCID: 0000-0002-5845-8343 \\ e-mail: nataliia.hensitska-antoniuk@rshu.edu.ua
}

\begin{abstract}
The article is devoted to the problem of the analysis the views of Ukrainian teachers on the development of didactic foundations for the creation of Mathematics textbooks. It is noted that the content of school textbooks is the embodiment not only of curricula and programs, but also the value system of a particular culture, which plays an important role in the socialization of the younger generation. It is emphasized that the textbook is the main means of teaching, which is based on general didactic and methodological principles of teaching.

In the article there were allocated didactic principles such as: activization of pupils' cognitive activity, comprehensive development of the person, integral influence of educational process, nature conformity of the organization of study, scientific, accessible, systematic and consistent in studying, continuity and prospects, the relationship between learning and development, motivational support of the educational process, cooperation, individualization and differentiation of learning, clarity, strength and effectiveness of learning outcomes, activity, educational learning, consciousness, intensity, optimization, interdisciplinary cooperation, intercultural interaction, etc.

It is substantiated that among the approaches to determining the didactic principles of the textbook a special place is occupied by the functional approach, according to which the main functions of the school textbook are: informative, transformational, systematizing, research, practical and self-educational function.
\end{abstract}




\section{Інноватика у вихованні. Випуск 13.Том 1. 2021.}

The attention is accented on the point of view that school Mathematics textbooks help to create a holistic system of teaching mathematics to pupils with a single unambiguous interpretation of concepts, unified terminology and provide not only the end result, but also the implementation of educational, developmental functions - the formation of highly educated, well-developed creative personality of Ukraine.

Keywords: Mathematics textbooks, views of Ukrainian teachers, didactic principles of textbook creation.

Стаття надійшла до редакиії 07.05.2021p. 